\title{
NEW TYPES OF TOURISM AND TOURISM MARKETING IN THE POST-INDUSTRIAL WORLD
}

\author{
László Arva and Zsuzsa Deli-Gray
}

\begin{abstract}
At the end of the $20^{\text {th }}$ century in the most developed countries economy and society went through profound transformation. The emerging post-industrial society can be characterised by the dominance of service industry, more leisure time of the population, higher disposable income and more conscious consumers. These conscious consumers are more and more quality orientated and reject undifferentiated mass products. New customers of tourism and hospitality industry are not only more affluent - so less price conscious - and more quality orientated but they are also seeking activity, participation, fantasy, and experience. These new types of tourists are interested rather in aesthetic aspects of life and are seeking highly differentiated, personalised experience. In the following article the authors, professors of the French ESSCA business school overview theoretical aspects of new, post-Fordist tourism demand and present examples of the new tourism and hospitality products having emerged in the developed countries during the last years.
\end{abstract}

Key words: tourism, tourism marketing, post-modern marketing, consumer behaviour, product development, new types of tourism

\section{Shift from Fordist to Post-Fordist Tourism Consumption and Production}

In order to be able to understand those new forms of tourism which emerged during the last decades, starting from the new types of educational tourism through the youth music festivals till the new types of entertainment centres at the highways, we have to overlook the new developments of tourism consumption theories briefly.

After summarizing the latest findings of tourism consumption theories, based on the works of Miles (1998), Saunders (1981) and Bourdieu, Shaw and Williams (2004) described the development of tourism consumption in the developed countries from Fordist type consumption to post Fordist consumption patterns.

Fordist type consumption was the product of the post WWII economic development, with longer paid holidays, wide use of cars, and increasing purchasing power. This tourism can be called mass tourism and according to Shaw and Williams (2004) its characteristics are the following:

o collective consumption by undifferentiated tourists

o Collective gaze of tourists - focused on signifiers designed to concentrate tourists' seasonally polarized consumption

o Demand for familiarity by tourists

o Undifferentiated product - similarity of facilities and experiences

o Rigidity of production - highly standardised, large scale, dependent on scale economies

o Low prices - importance of discontinuing and price cutting

o Large numbers of tourists to a circuit of mass production
The Fordist type of tourism consumption was the result of the "trente gloriouses", the thirty-year-long rapid economic development in Western Europe and in the USA between 1945 and 1975. The first and second oil crisis (1973-1977) and consequently, the introduction of new technologies computers, IT technologies, satellite communication - and new production methods - Toyota just in time system, foreign investments and multinational company structures speeded up the process of creation of the "Global Village" (McLuhan, 1962). In this "global village" information spreads at speed of light and the IT based technologies make the development of tailor made, specialised products for a differentiated market easier. With the spread of foreign investments and the development of the multinational companies, income differences also have started to grow rapidly and this contributed to differentiation of tastes and demands. The formerly homogenous middle class has become more differentiated and Bourdieu's definitions (1984) "new bourgeoisie" and "new petit bourgeoisie" have emerged.

This "new bourgeoisie" and "new petit bourgeoisie" are important taste makers, they are highly educated but their life-styles are different from that of the traditional bourgeoisie. The new bourgeoisie is active mainly in service industry and rich in economic and cultural capital, as the "new petit bourgeoisie" has much more modest economic capital but their educational level is very high (Shaw, G., and Williams, A.M., 2004). Representatives are mainly professors, teachers, journalists, and civil servants.

The emergence of the "new bourgeoisie" and New Petit Bourgeoisie" contributed to the appearance of the "postindustrial or post-Fordist mentality" and "post-industrial or post-Fordist consumption patterns". 
It is important to note that philosophers and sociologist are referring to this complex post-industrial attitude as postmodernism, stating that the modernist philosophical and artistic movement of the $20^{\text {th }}$ Century are greatly the off springs of the industrial, mass society with its mass consumption attitudes (see in the works of Lyotard (1984), Brown, (1997) or Shaw and Williams (2004)).

After the book of Urry (1995) Shaw and Williams summarized the pattern of post-Fordist or post modern tourism in the following table:

\begin{tabular}{|c|c|}
\hline $\begin{array}{l}\text { Characteristics of } \\
\text { post-Fordist consumption }\end{array}$ & Tourism examples \\
\hline $\begin{array}{l}\text { Consumers are increasingly } \\
\text { dominant and producers have } \\
\text { to be much more consumer } \\
\text { orientated }\end{array}$ & $\begin{array}{l}\text { Rejection of certain forms of mass } \\
\text { tourism (holiday camps and cheaper } \\
\text { packaged holidays) and increased } \\
\text { diversity of preferences }\end{array}$ \\
\hline $\begin{array}{l}\text { Greater volatility of consumer } \\
\text { preferences }\end{array}$ & $\begin{array}{l}\text { Fewer repeat visits and the proliferation } \\
\text { of alternative sights and attractions }\end{array}$ \\
\hline Increased market segmentation & $\begin{array}{l}\text { Multiplication of types of holiday and } \\
\text { visitor attraction, based on lifestyle } \\
\text { search }\end{array}$ \\
\hline Growth of consumers' movement & $\begin{array}{l}\text { Much more information provided about } \\
\text { alternative holidays and attractions } \\
\text { through the media }\end{array}$ \\
\hline $\begin{array}{l}\text { Development of many new } \\
\text { products, each of which has } \\
\text { a shorter life }\end{array}$ & $\begin{array}{l}\text { Rapid turnover of tourist sites and } \\
\text { experiences, because of rapid changes } \\
\text { of fashion }\end{array}$ \\
\hline $\begin{array}{l}\text { Increased preferences expressed } \\
\text { from mass forms of production/ } \\
\text { consumption }\end{array}$ & $\begin{array}{l}\text { Growth of 'green tourism' and forms of } \\
\text { refreshment and accommodation } \\
\text { individually tailored to the consumer } \\
\text { (such as country-house hotels) }\end{array}$ \\
\hline $\begin{array}{l}\text { Consumption as less and less } \\
\text { functional and increasingly } \\
\text { aestheticized }\end{array}$ & $\begin{array}{l}\text { 'De-differentiation' of tourism from } \\
\text { leisure, culture, retailing, education, } \\
\text { sport, hobbies }\end{array}$ \\
\hline
\end{tabular}

New types of tourism demand have profoundly changed tourism supply and tourism marketing activities as well. Differentiated product development and differentiated marketing became more important and generation of experience became important practically in all tourism products. At the same time, visitors are not only passive consumers of experience but would like to participate in the generation process of the experience actively.

In the next pages we will present examples of these newtyped tourism products and new types of tourism marketing activities from Hungary, by describing some new types of motorway highway stations, new forms of festival tourism and new forms of educational tourism.

\section{Analysis of new tourism products}

\subsection{Motorway highway stations}

Post-modern tourism experience can perhaps be illustrated the in the best way by the example of new types of motorway service stations in Europe.

The development of highway service stations started in Europe after the WWII with the highway construction boom in Germany, Italy and France. Traditionally highway service stations have offered the travellers gasoline and some snacks in small rapid restaurants in the vicinity of the filling stations. Sometimes smaller motels were built in the area mainly for long distance truck drivers.

As in the 60s personal cars became more widespread in the middle class and as people could enjoy longer holidays, more and more families started to travel by cars to the seaside or to the mountain ski resorts. This was the time of mass family tourism and highway service stations started to get adapted to the changing demand.

The first step of adaptation was generally the enlargement and modernization of the cafeteria at the filling station in order to attract other clients than the long haul truck drivers. The next step in Western Europe, mainly at the end of the eighties and at the beginning of the nineties was, that separate catering and hospitality centres appeared at the highway service stations, generally approximately 100-150 meters from the filling stations. In these catering and hospitality centres everything was about to serve the middle class travellers. Restaurants, grill bars, coffee shops, souvenir shops, business lounges and even smaller conference rooms are waiting for the travellers in the new catering and hospitality centres, which in Austria are mainly operated by the Rosenberger, the Marché or the Italian Autogrill companies. In these catering and hospitality centres also smaller, 3 star hotels with 5-10 rooms can generally be found. The hotel facilities are also aiming the families and business voyagers instead of the truck drivers. The choice of food and beverages are much greater in these centres than in the old-fashioned quick restaurants at the filling stations or in the traditional road side inns. They are targeting the typical demanding, well off new middle class travellers, let they be on business trips on family excursions.

In Hungary similar centres have just been built beside the M1 highway at Mosonmagyaróvár and at the Budapest MO periphery highway. They are all operated by the Swiss Marché group.

Though these new catering and hospitality centres are relatively new establishments, targeting new middle class travellers, this is not the last word of the development of the catering and hospitality centres beside the highways.

The new, we would say "post-modern" catering and hospitality centres at the highways are different from the traditional catering and hospitality centres not only in their appearance but in their marketing philosophy as well. As the traditional centres do not want to be anything else than high quality and efficient places beside the highways, where middle class travellers can have a shorter or longer stop-over, and where they can eat, refresh or perhaps spend a night or can have shorter company meetings, the new "post modern" centres want to give special experience to the travellers.

Typical example of these post modern catering and hospitality centres are operated by the Austrian Oldtimer company. The Oldtimer catering and hospitality centres are highly visible from the highways. These centres - there are four ones in Austria today - are rather eccentric 
architecturally, and catch the eyes of the travellers. Beside one of the Oldtimer centres there is an oversized pirate ship, where children can play if they wish. The internal setup of these centres is also unique and rather eccentric, too. In these centres travellers can also find restaurants, coffee shops, conference rooms and small hotels, just like in the more traditional catering and hospitality centres, but the internal decoration of these facilities is different. Some old furniture can be found here; there is an old motorbike and at the corner an armoured cavalier is watching the guests. The walls are covered by wooden sculptures in the famous Hundertwasser style.

The Oldtimer Centres are close relatives of the Disneyland castles and their aim is also the same: to create special experience for children and for the adults who have kept the child in their hearts. Naturally these centres are not only passive spaces of the childhood nostalgia as in case of special Oldtimer car meetings, special country music festivals and other events.

Children play a special role in the marketing philosophy of the Oldtimer centres. The marketing managers of the Oldtimer company have realized that more and more middle class families travel on the highways with children. Business travellers travel by airplanes or express trains but families generally prefer cars as it is easier to carry all the equipment, toys and sport gears needed for the children than by airplane or by trains. And as the children are the apples of the middle class families, naturally they will have a short stop-over where the children wish - and they prefer pirate ships, wonderland and the armoured cavaliers of the Oldtimer Centres.

The Oldtimer Centres are typical examples of Disneyfication of tourism and catering - creation of experience in the everyday activities, even in the middle of the highways, between Vienna and Graz.

The slogans of these centres are: activity, participation, fantasy, entertainment and fun.

\subsection{New types of educational tourism}

Students travelled to faraway places even in the Middle Ages in order to be able to learn from the best professors of their time. Universities were founded in the peripheral countries in Europe only later, and never became as important as the traditional Western Universities in Heidelberg, in Berlin, in Paris.

Till the emergence of "new educational tourism" universities had practically only one unique "marketing tool" to attract foreign students: to invite the best known professors to their cathedras.

Today higher educational mobility has a completely different new aspect. Educational mobility today is getting more and more as much a tourist activity as an educational one. In our days according to the OECD more that 4 million students study abroad at colleges and universities all over the world. Half of the students arrive from the newly industrialized countries and they are sons and daughters of the new middle class, who can afford to travel to the developed countries. The proof of it is that the majority of the students arrive in the USA, Western Europe and Australia.

Naturally, one of the major aims of the foreign students arriving at the universities of the developed countries is to learn, but the emphasis from the big names of certain professors has shifted to the general judgement of the universities which is mainly measured by the university ranking list, produced generally by the great journals and magazines.

But besides learning other aspects are also getting more and more important for the students arriving from abroad.

These aspects are the following:

o the general level of development of the country where the university is working

o ambience of the university town

o tourist attractions in the vicinity of the university

o sporting facilities and other entertainment possibilities of the university

o general ambience of the university.

As priorities of students regarding to their university choice are changing, the marketing activities of the universities also have to develop. In case of ESSCA, Ecole Superiuere des Sciences Commerciales d'Angers, the leading business school of France, besides providing high level academic programmes, which is the highest priority, internationalization and organizing programs for the students getting more and more important. That is why ESSCA has created filials in Budapest and Shanghai where students who have started their studies in France can continue their studies and can get acquainted with completely different general and company cultures. Internationalization makes it necessary to have partnership with other universities from where students and professors arrive at ESSCA, and naturally students of ESSCA also can spend one or two semesters in these partner universities.

Beside the internationalization it is extremely important to provide facilities for students for their after-learning hour activities. Sport halls, entertainment centres are also provided for the ESSCA students. As after-class entertainment is regarded very important, special evenings are organised for the students by the university where they can present their home culture for the students of other nations.

For universities it is very important to have foreign students as in the developed countries their number is generally declining because of the well known demographic trends. To attract students they need well designed marketing activity, where, beside the traditional academic values, tourist aspects have to be taken into consideration as well. Naturally it is a great danger to overemphasize tourist aspect against the traditional academic values as even today the core product of the universities should be knowledge, but the auxiliary tourism products around it is getting more and more important.

\subsection{New musical youth festivals in Hungary}

Before 1990 different musical groups organized summer camps for their fans and similarly folk music and folk art camps and events were also organised sporadically. At the 
beginning of the 90 s two independent initiatives emerged to organise summer youth festivals, where not only the fans of one type of activities or of one music style could find their interesting programs but these several-day-long festivals could attract youth having completely different interest. The idea was to organise a festival with highly differentiated products for highly segmented customers.

As we have mentioned this idea came to the mind of the group leader of the successful Hungarian pop group, named Sziami, Peter Muller and independently from him to the avant garde composer, Istvan Marta.

Though the target group in each case was the same, realization of the "product" was different: Peter Muller started to work out a Music Festival in the heart of Budapest, István Márta wanted to organize his festival in the countryside. In both cases the main target group were the well off young people, interested in music, but in case of Muller's project the stress was on pop music, in case of Marta' project folk music and amateur performances were also part of the menu.

From Peter Muller's idea the famous Sziget Fesztival (Island Festival) has emerged which has become one of the most important music festivals of Europe with nearly 400000 visitors in 2009, and from Istvan Marta's idea the also famous Kapolcs Art Festival was born, which has also attracted tens of thousands of young Hungarian and foreign visitors during the last years.

As both festival were highly successful regarding the number of visitors, the Sziget Fesztival of Peter Müller has generated increasing volume revenue and profit, Kapolcs Art Festival was a financial disaster and in 2009 it seemed that it would die away forever because of the financial problems.

What were the causes of these differences in profitability of the two festivals? First of all, Sziget Fesztival as a product has attracted largest number of visitors because besides the local groups real big pop stars could be invited just because of the solid and every year increasing revenue of the event. On the other hand Kapolcs Art Festival could never get rid of a certain flair of amateurism, as the events were dominated by less widely known performers and ensembles.

But it was more important that in case of Sziget Fesztival the whole process was organised in an excellent way, while the process of the organisation was more haphazard and occasional in case of Kapolcs Art Fesztival.

In case of Sziget Fesztival, the events were organized in the hearth of Budapest, at an easily accessible place, on an island. It is important that to this island the visitors can enter only through a limited number of entrances, across bridges, so entrance fee can be easily collected. Companies were also eager to sponsor the event as very large number of visitors gathered at a relatively limited place where their information had a large chance to reach the young people participating at the festival.

In case of Kapocs Art Fesztival, events were scattered around a dozen of villages, and the entrance of visitors could not be controlled and entrance fees could not be collected as there were altogether more than 7 big roads and numberless side roads where anyone could enter the festival sites.
Revenue of the festival entered into the owners of the restaurants, hotels and even gardens where visitors had to pay for tent places. Sponsors were not happy with the participation of large number of villages in the festival as relatively small number of visitors presented at each site.

Regardless of the differences in financial performance of the two festivals, both are good examples of the new types of festivals aiming the demanding and relatively well off new middle class youth as target group. It is also important that in both cases the festival offers good opportunities for young people to meet each other, and this aspect of the events perhaps has attracted as many visitors as many big names of pop music, who performed at these festivals.

In both festivals - regardless of the relatively large number of participants - the programmes are highly differentiated for the different audiences. For the participants active participation and interaction are very important elements.

\section{Some conclusions}

As in service industry generally, in tourism the changing demand is generating new products, and/or changing the faces of the old products. New bourgeoisie and new petit bourgeoisie with their new post-modern attitudes demand products which are radically different from the old style mass tourism products. These new customers are more informed, have higher disposable income, need more freedom in their choices, reject "passive gaze" and are more active. As they are spending a lot of time in front of the computer, they are not only more informed but at the same time they live in a virtual world as well, so they need more fantasy - some Disneyland effects are always welcome by these customers.

Tourism marketing also has to get adapted to the new consumer behaviour.

Old products are reappearing in new forms and completely new products are developed in order to meet the changing needs of the new customers.

The life cycle of products is getting shorter, market segmentation is getting more difficult and the market segments are getting smaller. Products are more targeted.

In the previous examples we could see that activities, which had formerly no or insignificant tourist elements - like education -, today have a lot of tourist aspects. We saw that traditional, even a little "boring" services like highway-side service stations can be transformed into Disney-like fantasy land entertainment centres, universities get tourism aspects and single product music festivals are changing into multi product, week long festivities.

The slogans of new tourism marketing are:

- "Participation,

- Entertainment

- Fantasy

- Personalization and

- Fun" 
These are the basics of tourism product development in our days and these could guarantee the satisfaction of the new, affluent, informed and educated customers in tourism.

\section{References}

Belk, R.W. (1995): Studies in the new consumer behaviour. In: Miller, D. Acknowledgeing Consumption, Phaidon, London.

Bourdieu, P. (1984): Distinction: A social critique of judgement of taste. London, Rutledge and Kegan Paul.

Holloway, J. Ch. (2002): The Business of Tourism. 6th Ed. Person Educational Ltd. Harlow.

KSH (2007): Jelentés a turizmus 2006 évi teljesítményéről. Budapest, 2007

Brown, Stephen (1997): Postmodern marketing. International Thomson Press, London

Firat, A.F. et al. (1995): Marketing, in a postmodern World, European Journal of Marketing, Vol. 29. No. 1.

Holloway, J. Ch. (2002): The Business of Tourism. 6th Ed. Person Educational Ltd. Harlow.
McLuhan, M. (1962): The Gutenberg Galaxy: Making of the Typographic Man. Univ. of Toronto Press. Toronto.

Lyotard, Jean-François (1984): The Postmodern Condition: A Report on Knowledge. Minneapolis: University of Minnesota Press

MacCannell, D. (1976): The tourist: A New Theory of the Leisure Class, New York: Sulouker Books.

Miles, S. (1998): Consumerism as a way of life. London, Sage OECD [2007]: Education at a Glance. OECD.

Oktatasi Statisztikai Evkonyv (2006): (Statistical Yearbook of Education) 2005/2006, Ministry of Education and Culture, Budapest,

Ritchie, B.W. (2003): Managing Educational Tourism. Aspects of Tourism 10. Channel View Publications, Clevedon.

Ritzer, G. (1995): The McDonaldization Thesis. London, Sage.

Ritzer and Liska (1997): "McDisneyization" and "Post Tourism": complementary perspectives on complementary tourism. in: C. Rojek and J. Urry (eds): Toursing Cultures, Londons, Routledge.

Shaw, G., - Williams, A.M. (2004): Tourism and Tourism Spaces. SSGR Publications, London

Urry, J. (19995): Consuming Places, London, Routledge 